ISMC 2021

$16^{\text {th }}$ International Strategic Management Conference

\title{
IN THE PROCESS OF THE CORONAVIRUS OUTBREAK COMMUNITY NUTRITION AND ECONOMIC MANAGEMENT
}

\author{
Kâmil Tüğen (a)*, Aslihan Tüğen (b) \\ *Corresponding author \\ (a) Dokuz Eylül Üniversity, Faculty of Economic and Administratives Sciences, Buca-İzmir-Turkey, \\ kamil.tugen@deu.edu.tr \\ (b) Afyon Kocatepe Üniversity, Institute of Graduate Studies in Science, Food Engineering Department, Afyon- \\ Turkey, asl_tugen@windowslive.com
}

\begin{abstract}
The coronavirus (COVID-19), which emerged in late December 2019, has become a global epidemic since the beginning of March 2020. In the countries of the world and in Turkey, the number of people infected with coronavirus and the cases of death have increased rapidly. While restrictions are imposed on social life against the spread of the coronavirus, on the other hand vaccines have been developed by countries such as China, the USA, England, Germany, the Russian Federation and India. During the coronavirus epidemic process, the issue of community nutrition has come to the fore among various social needs, and social sensitivity in food production, consumption and nutrition has increased under hygienic conditions in the fight against coronavirus. Production and consumption activities take place in the economy, and developments in production and consumption have an impact on the growth/shrinking of the country's economy. With the coronavirus epidemic, countries have revised their economic growth targets and economic growth rates have decreased. With the slowdown of the epidemic and the transition to normalization, economic growth rates began to rise to and above pre-epidemic levels.
\end{abstract}

2357-1330 @ 2021 Published by European Publisher.

Keywords: Coronavirus, community nutrition, economy management 


\section{Introduction}

The coronavirus (COVID-19), which emerged in the China's Hubei city of Wuhan, at the end of December 2019, has spread rapidly at the global level since the beginning of March 2020. Although the world has witnessed large-scale epidemics in the past, especially at the beginning of each century of the last three centuries, the coronavirus epidemic has been the largest epidemic ever experienced. There is no country or region in the world that is not affected by the epidemic. The epidemic has affected many people, professionals, from citizens on the street to statesmen such as the president of the United States and the Prime Minister of the United Kingdom. In this process, countries have lost many well-known people, especially in the health sector. Therefore, the epidemic caused a serious loss of human capital.

The coronavirus epidemic has affected every aspect of life. One of the most affected areas has been "community nutrition" concept. A healthy society nutrition is important for a healthy society. A healthy society is an indispensable element of a stable economy and economic growth.

In this article, we will mention that the developments revealed by the epidemic process by considering community nutrition and economic relations during the coronavirus epidemic process. In the preparation of the paper, our observations were used, and some results were obtained by making a literature review on the subject.

\section{Improvements in the Coronavirus Outbreak}

Countries were caught unprepared for the coronavirus epidemic. At the beginning of signs of the epidemic being seen, the necessary measures could not be taken at the border gates and airports in a timely manner, probably due to the lack of foresight about the rate of spread of the epidemic. As in Turkey, the West and other countries, extensive measures have been taken since the beginning of 2020 March to prevent the spread of the virus. As the epidemic showed a certain expansion and spread rapidly, a restriction was urgently imposed on formal education in the first plan. Approximately, 1.5 billion children interrupted their education as a result of the measures and restrictions taken due to the epidemic. After a short break, education services at all levels started to be offered via the internet, which is a great success. It was possible to talk about the existence of distance education infrastructures of educational institutions over the internet to a certain extent before the epidemic, but it was not easy to maintain the supply-demand balance caused by the pandemic. The education services at all levels in our country and in other countries have been carried out via distance education over the internet since 2020 March. The new formal education method in accordance with the application principle is also maintained according to the rules of medical mask, social distance and hygiene. With the impressions of the epidemic, face-to-face trainings were also started at certain times in the first education stages. On the other hand, the progress of vaccine studies against coronavirus, the development of vaccines and the spread of vaccine applications in the community have enabled the relaxation of coronavirus measures and the transition to normalization.

Towards the middle of March 2020, nearly 7,000 people in the world died from the coronavirus. By the end of May 2020, the figure mentioned in March increased to over 350 thousand (4461 in the republic of Turkey). In June 2020, close to 500 thousand in the world (5 thousand in the republic of 
Turkey), more than 660 thousand in July 2020 (5659 in the republic of Turkey), more than 850 thousand in August 2020 (6326 in the republic of Turkey), 940 thousand 720 in the world (7249 in the republic of Turkey) in mid-September 2020, person died due to pandemic. The above-mentioned number of deaths recorded at the beginning of December 2020, exceeded 1.5 million in the world (close to 15 thousand in the republic of Turkey). Based on the increase in coronavirus cases and the increase in the number of deaths, the restrictions were reinstated, but the decreasing number of cases with the widespread use of vaccines paved the way for a return to normalization in economic and social life as of July 1, 2021, in our country. At the end of July 2021, close to 4.5 million people in the world died from the coronavirus, while more than 50,000 people died in our country. While these statistics for the world were recorded as 4,557,490 at the beginning of September 2021, it was reported as 57,283 people for our country.

"When will the epidemic end?" It is not possible to say anything definite about this issue, but it can be said that the economic and social life will continue to increase its gains during the epidemic. When normalization is passed and face-to-face education begins, education will continue under hygienic conditions, and many areas of life will continue to move to the internet environment, computer screen, and the real space to the virtual space.

\section{Community Nutrition During the Coronavirus Epidemic}

According to the United Nations World Food Security Committee, "food security" means that all people always have physical, social and economic access to sufficient, safe and nutritious food that meets their food and dietary needs for an active and healthy life. Climate change, increasing global population, regional conflicts, migration movements, rising food costs, environmental changes etc. creates significant uncertainties on food safety. The coronavirus epidemic has increased the existing problems and uncertainties.

In 2015, the United Nations (UN) 2030 Agenda for Sustainable Development announced 17 Sustainable Development Goals (SDGs), which include an urgent call to action for developed and developing countries. Ending hunger, ensuring sustainable consumption and production by ensuring food safety and improved nutrition are among the goals of food systems. These include halving global food waste per capita at the retail and consumer levels, reducing food losses in supply chains, promoting healthy living and promoting well-being for all ages. The environmental and economic impacts of food waste account for at least $15 \%$ of the impacts of the entire food value chain (Galanakis, 2020).

The coronavirus epidemic has threatened and will continue to threaten the food security and nutrition of millions of people. In the long run, we are face to face that the potential disruptions to the functioning of food systems that could have serious health and nutritional consequences. Concerted actions are needed to ensure a transition to more sustainable food systems that are in better balance with nature, promote healthy eating and thus meet better health expectations for all situations (United Nations, 2020).

By 2020, the number of hungry and malnourished people worldwide was increasing. Today, more than 800 million people face chronic malnutrition and more than 100 million need life-saving food aid. The coronavirus has adversely affected the efforts of humanitarian and food security organizations that want to reverse these trends (Sova, 2020). 
As Shenggen Fan who is the former Director General of the International Food Policy Research Institute (IFPRI) said: "COVID-19 is a health crisis. But if appropriate measures are not taken, it can also lead to a food security crisis" (Sova, 2020, para. 2).

The following recommendations have been put forward for General Food Safety in the conditions of the coronavirus epidemic (Unhale et al., 2020):

- Buy raw materials from reliable sources.

- Cook foods thoroughly and maintain safe storage temperatures.

- Clean surfaces (cooking boards, refrigerator handles, etc.) and sterilize equipment.

- Properly educate staff in taking hygiene measures.

- Employees who are showing signs of communicable disease should not come to work.

- Implement appropriate risk management strategies (for example, support online meetings)

- The number of staff in the kitchen or food preparation area should be kept to a minimum.

- If possible, separate workstations and food preparation areas.

The Food and Agriculture Organization of the United Nations (FAO) also makes the following recommendations (United Nations, 27 March 2020):

- Consume a variety of foods within each food group and across all food groups to ensure adequate intake of important nutrients.

- Consume plenty of fruits and vegetables. Fresh fruits and vegetables provide many vitamins and minerals, as well as the fiber we need for a healthy diet. You can buy frozen or canned fruits and vegetables as well as fresh fruits and vegetables to limit your trips to the market or supermarket. However, other ingredients such as sugar, salt or preservatives are sometimes added in the canning and processing of these products. Be sure to read the labels so you can choose the best options for you and your family to limit the intake of these ingredients.

- Follow a diet rich in unsaturated healthy fats such as whole grains, nuts, and oilseeds. Such diets can support your immune system and help reduce inflammation.

- Pay attention to the intake of fat, sugar and salt. Most people use food to relax during very stressful times, which can lead to excessive consumption. In addition, foods that contain fat, sugar, salt that are high in calories are often very delicious. Try to avoid consuming too much of these ingredients. Food labels are always useful. In this way, consumers can ensure that food components that should only be present in certain quantities in a healthy diet are purchased and consumed.

- Continue to apply food hygiene rules. Because of the Coronavirus outbreak, you may be more concerned about food safety; but coronavirus is a respiratory virus and not a food-borne disease. There is no evidence that the disease can be spread through contact with purchased food.

Coronavirus is mainly transmitted through respiratory droplets during speech (FAO, 2020).

The restrictions on curfews have caused some interruptions in food supply chains, and significant increases have occurred in food prices, along with difficulties in accessing some foods. In addition to needs such as food stocking in homes, trends in addressing these needs with domestic production have 
strengthened. On the other hand, agricultural activities have been negatively affected due to disruptions and disruptions in non-food supply chains such as fertilizers and other critical inputs (Sova, 2020).

According to the research, the main reasons for the emergence of epidemics caused by noroviruses that can be transmitted through the respiratory tract are usually the infections caused by employees who do not show symptoms (Lamhoujeb et al., 2008).

Food business operators should educate their employees on personal hygiene and business hygiene and warn them about how to use personal protective equipment such as masks and visors.

The ability of the coronavirus to survive on surfaces is limited. For this reason, the way to minimize the risk of contamination of foods purchased from the market may be to store these foods in a separate area for a while (considering the survival time of the virus on surfaces -like three days). The coronavirus is an "enveloped virus", and soap is effective in disrupting the structure of the virus, and water causes the virus to be removed by moving away from the surface (Aslan, 2020).

Food can be produced and served safely for consumers by preventing the development of pathogens and spoiling microorganisms in foods, usually by heat treatments applied together with $\mathrm{pH}$, moisture contents and water activities. However, the basic approach that should be implemented in order to protect from viruses is to protect food from environmental contamination as much as possible (Bosch et al., 2018).

During the coronavirus epidemic, it is important for people to eat adequate and balanced nutrition under hygienic conditions and strengthen their immune systems. It is a well-known fact that to gain a balanced diet rich in vegetables and fruits in order to regularly provide copper, folic acid, iron, selenium, zinc and vitamins A, B6, B12, C and D, which play an important role in a strong immune system (FAO, 2020). In addition, drinking enough water, exercising, walking and getting enough sleep are the most important factors in strengthening immunity. Drinking plenty of water (at most 6-8 glasses a day for adults) also helps our immune system. Drinking plain water instead of sugar-sweetened beverages also helps reduce the risk of consuming too many calories to maintain a healthy weight (FAO, 2020). Some habits that harm the immune system, such as alcohol and smoking, should also be avoided.

Compared to children and young people, the elderly and those with chronic diseases suffer more from coronavirus. It has less impact on coronavirus cases in individuals defined under the name of child. The World Health Organization (WHO), the World Food and Agriculture Organization (FAO) and the United Nations Children's Fund (UNICEF) are working on the nutrition of children, which will be on the agenda with the return to normal in education.

According to the UN-FAO's Food Price Index, which tracks prices for a wide range of products from around the world, from cereals to oil, dairy products to meat and sugar, global staple food prices increased by $39.7 \%$ in May 2021 compared to the same period last year. The fact that food producers were affected by the cuts in production, employment and transportation during the epidemic and the increase in costs played a major role in this increase (BBC Turkey, 2021). On the other hand, while the Food Price Index for June 2021 decreased by $2.5 \%$ on a monthly basis, there was an increase of $33.9 \%$ in the index compared to the same month of the previous year. The decrease on a monthly basis was due to the decrease in vegetable oils, cereals and dairy products prices (Çetinkaya, 2021). The index increased 
by $3.1 \%$ compared to July 2021, the increase in the index was $32.9 \%$ in August 2021 compared to the same period of the previous year (Gönültaş, 2021).

According to the statistics seen in the data, the coronavirus epidemic caused a general increase in world food prices, which had negative effects on the social income distribution and on the nutrition of the society, considering that most of the society consists of middle- and low-income people.

\section{Economy Management During the Coronavirus Epidemic}

In order to reduce the effects of the coronavirus epidemic on economic, financial and social life, a series of support measures have been taken and put into effect by governments for those affected by the epidemic. Central Banks have increased the money supply, the International Monetary Fund (IMF) has created a large pool of long-term, very low interest loans. Economic growth forecasts have been lowered.

With the measures taken during the epidemic, it was tried not to interrupt the production activities in the companies that produce the basic needs. However, the restrictions imposed on the services sector (restaurants, cafes, game rooms, etc.) negatively affected the employees in this sector economically. Governments have tried to alleviate the problems to some extent with financial support packages. According to OECD data, financial support at the global level has reached 13.8 trillion dollars. The deadlines for filing returns and paying taxes have been extended. Unpaid taxes, premiums, etc. financial obligations were restructured.

Before the epidemic, countries had certain economic problems. Foreign trade balance, budget balance, economic growth, unemployment, inflation, debt payments, etc. economic indicators were generally gloomy. With the epidemic, the governments of the countries, despite the rules related to fiscal discipline, have turned to expansionary monetary policies and increased money printing.

The World Trade Organization (WTO) encouraged member countries to take measures to facilitate foreign trade and reduce bureaucracy, and the positive effects of these incentives were observed. The world trade volume, which fell into decline at the beginning of the epidemic, has returned to its previous levels.

It is above all appreciation in terms of social solidarity that the people who were greatly affected by the epidemic, suffered loss of income, and had difficulty in paying, did not turn to reaction movements, followed the developments with patience and tolerance, and followed the government measures that considered the opinions of scientific committees.

Moving life more into virtual environments creates important problems in terms of the moral values and psychology of a person who is a social being and will lead to more. In order to reduce these problems, more organizations will be needed that will bring people together on various decks.

Economic growth rates of countries began to rise with a certain slowdown of the epidemic process and steps of normalization. However, increases in the money supply, made without an economic equivalent, will raise inflation, interest rates, and increase unemployment. Therefore, towards the end of the epidemic process, it would be appropriate for governments to focus their efforts on economic stability. Economic stability is of great importance for starting to solve economic and social problems. 


\section{Conclusion}

The coronavirus outbreak has ushered in a new era in the food supply chain and in the food industry. Researchers and professionals in the food industry have many responsibilities, such as ensuring food safety, detecting coronavirus in the environments where food is produced, processed and delivered, and adequate disinfection of surfaces and working environments. Currently, the possibility of COVID-19 transmission through the food sector is considered negligible, while monitoring for coronavirus in the food sector and surrounding environments is not seen as a priority for public authorities (Galanakis et al., 2020).

The Chinese government has had important implications for the food industry during the coronavirus process. The government has focused on public health to improve the public's knowledge of food safety and change unhealthy eating habits. Considering that the number of internet users in China has reached 854 million, the survey on public health during the epidemic is representative (Shi et al., 2020).

The coronavirus outbreak has been an important mechanism for the Chinese to improve their food safety-related behavior by focusing on food safety-related information. Empirical analyzes reveal that the food safety information of the epidemic has a significant and positive effect on food safety behaviors (Shi et al., 2020).

On the other hand, the epidemic has also changed consumer behavior. For example, a survey conducted in North Macedonia showed that the epidemic has significantly changed the shopping behavior of consumers regarding their food purchase and consumption. While consumers in North Macedonia bought reasonable amounts of food as they needed before the outbreak began, during the epidemic, consumers began to buy larger quantities of food from supermarkets (Bogevska et al., 2021).

- To protect people from the far-reaching effects of the coronavirus epidemic, additional efforts by governments and those responsible are needed in the following areas:

- To create business areas instead of business areas that started to disappear due to the epidemic,

- Developing community support packages that include urban and rural safety net programs,

- Reviewing and increasing state aid to major economic sectors,

- Expanding, strengthening and maintaining public awareness campaigns, including agricultural activities,

- Improving access to health and education services for all (Habtewold, 2021).

As a result, there are duties that fall on individuals, institutions, states, and the United Nations Organization in order to get the coronavirus epidemic off the agenda. It is an all-out struggle. While people pay attention to mask, social distance and hygiene rules, while they are vaccinated, institutions should pay attention to the implementation of these rules while serving. Governments must ensure the functioning of social life with the measures they will take and the economic, financial and social policies they will implement. An important element of these measures and policies is meeting the nutritional needs of society in terms of economic, quality and health. Because, in the ranking of social needs, nutrition and food come first. There has been a huge increase in food prices around the world during the Coronavirus outbreak since March 2020. However, due to the fact that states have taken the necessary 
measures to maintain food production, the World Trade Organization (WTO) has directed member states to take measures to facilitate foreign trade, excessive growth in food prices in the world has been prevented.

\section{References}

Aslan, D. (2020, April 5). COVID-19: Gıda Sağlığı ve Gıda Güvencesi Üzerine [COVID-19: On food Health and Food Safety]. Halk Sağlığı Uzmanları Derneği (Hasuder) Covid-19 Görev Grubu. https://korona.hasuder.org.tr/gida-sagligi-ve-gida-guvencesi-uzerine/

BBC Turkey. (2021, June 4). Gıda fiyatları: Birleşmiş Milletler, küresel gıda fiyatlarının Mayıs'ta yıllık bazda 2010'dan bu yana görülmedik düzeyde arttığını açıkladı [Food prices: UN says global food prices rose year-on-year in May at an unprecedented rate since 2010]. https://www.bbc.com/turkce/haberler-dunya-57357170

Bogevska, Z., Berjan, S., El Bilali, H., Allahyari, M. S., Radosavac, A., \& Davitkovska, M. (2021). Exploring food shopping, consumption and waste habits in North Macedonia during the COVID19 pandemic. Economic Planning Sciences, In press. https://doi.org/10.1016/j.seps.2021.101150

Bosch, A., Gkogka, E., Le Guyader, F. S., Loisy-Hamon, F., Lee, A., van Lieshout, L., Marthi, B., Myrmel, M., Sansom, A., Schultz, A. C., Winkler, A., Zuber, S., \& Phistern, T. (2018). Foodborne viruses: Detection, risk assessment, and control options in food processing. International Journal of Food Microbiology, 285, 110-128. https://doi.org/10.1016/j.ijfoodmicro.2018.06.001

Çetinkaya, Z. (2021, July 8). FAO: Küresel gıda fiyatları 12 ay sonra ilk kez düştü [Global food prices fall for the first time in 12 months]. https://www.aa.com.tr/tr/dunya/fao-kuresel-gida-fiyatlari-12ay-sonra-ilk-kez dustu/2298089

Galanakis, R. M., Aldawoud, M. S., \& Galanakis, C. M. (2020). Safety of foods, food supply chain and environment within the COVID-19 Pandemic. Trends in Food Science \& Technology, 102, 293299. https://doi.org/10.1016/j.tifs.2020.06.008

Galanakis, C. M. (2020). The Food Systems in the Era of the Coronavirus (COVID-19) Pandemic Crisis. Foods, 9, 523. https://doi.org/10.3390/foods9040523

Gönültaş, B. (2021, September 2). FAO: Küresel gıda fiyatları 2 aylık düşüşün ardından yeniden yükselişte [Global food prices rise again after 2 months of decline]. https://www.aa.com.tr/tr/ekonomi/fao-kuresel-gida-fiyatlari-2-aylik-dususun-ardindan-yenidenyukseliste/2353539

Habtewold, T. M. (2021). Impacts of COVID - 19 on food security, employment and education: An empirical assessment during the early phase of the pandemic. Clinical Nutrition Open Science, 38, 70. https://doi.org/10.1016/j.nutos.2021.06.002

Lamhoujeb, S., Fliss, I., Ngazoa, S. E., \& Jean, J. (2008). Evaluation of the persistence of infectious human noroviruses on food surfaces by using real-time nucleic acid sequence-based amplification. Applied and Environmental Microbiology, 74, 3349-3355. https://doi.org/10.1128/AEM.02878-07

Shi, M., Cheng, X., \& Xiao-heng, Z. (2020). Impacts of the COVID-19 pandemic on consumers' food safety knowledge and behavior in China. Journal of Integrative Agriculture, 19(12), 2926-2936. https://doi.org/10.1016/S2095-3119(20)63388-3

Sova, C. (2020, March 30). Coronavirus and the 5 major threats it poses to global food security. Virus risks undermining efforts to reverse trend of rising hunger. World Food Programme. https://www.wfp.org/stories/coronavirus-and-5-major-threats-it-poses-global-food-security

The Food and Agriculture Organization of the United Nations (FAO). (2020). Maintaining a healthy diet during the COVID-19 pandemic. https://doi.org/10.4060/ca8380en

Unhale, S. S., Ansar, Q. B., Gajghane, V., Bharudkar, S. S., Gadekar, P. P., \& Biyani, K. R. (2020). Impact of Covid-19 on Food Safety and Food Security. World Journal of Advance Healthcare Research, 4(3), 128.

United Nations. (2020). Policy Brief: The Impact of COVID-19 on Food Security and Nutrition. United Nations. https://www.un.org/sites/un2.un.org/files/sg_policy_brief_on_covid_impact_on_food_ security.pdf 